\title{
PENGARUH PERCEIVED VALUE DAN KEPUASAN PADA LOYALITAS PENGGUNA KARTU SELULER DI KOTA PURWOKERTO DENGAN VARIABEL VARIETY SEEKING SEBAGAI VARIABEL MODERASI
}

\author{
Alisa Tri Nawarini \\ Jurusan Manajemen, Fakultas Ekonomi dan Bisnis Universitas Jenderal Soedirman Purwokerto. \\ Email corrresponding author : alisa.3.nawarini@gmail.com
}

\begin{abstract}
Customers' loyalty is a very important thing for companies to survive. This research has the aims to examine the effect of perceived value and customers' satisfaction to customers' loyalty with variety seeking role as moderating variable. This research is quantitative research with survey method. Sampling method used in this research is purposive sampling by taking 100 cellular card users in Purwokerto city. Data analysis methods used in this research are multiple regression analysis and moderated regression analysis. The research results show that: 1) perceived value has positive effect on customers' loyalty, 2) customers satisfaction has positive effect on customers' loyalty, 3) variety seeking moderating the effect of customers satisfaction to customers loyalty. The research implication is that companies cellular card provider is need to design their marketing programs to retain their customers' loyalty.
\end{abstract}

Keywords : perceived value, customers satisfaction, customers loyalty, variety seeking

\begin{abstract}
ABSTRAK
Loyalitas pelanggan merupakan hal yang sangat penting bagi perusahaan untuk bertahan di tengah persaingan. Penelitian ini bertujuan untuk menganalisis pengaruh persepsi nilai dan kepuasan pelanggan terhadap loyalitas pelanggan dengan kecenderungan mencari variasi sebagai variabel moderasi. Penelitian ini adalah penelitian kuantitatif dengan menggunakan metode survey. Metode pengambilan sampel yang digunakan adalah metode sampel purrposif dengan mengambil data 100 orang pengguna kartu seluler di kota Purwokerto. Metode analisis yang digunakan dalam penelitian ini adalah analisis regresi berganda dan analisis regresi dengan moderasi. Hasil riset menunjukkan 1)persepsi nilai memiliki pengaruh positif terhadap loyalitas pelanggan,2) kepuasan pelanggan memiliki pengaruh positif terhadaop loyalitas pelanggan, 3) kecenderungan mencari variasi memoderasi pengaruh kepuasan pelanggan terhadap loyalitas pelanggan. Implikasi penelitian menunjukkan bahwa perusahaan penyedia kartu seluler harus merancang program pemasaran yang efektif untuk untuk mempertahankan loyalitas pelanggan. Kata kunci : persepsi nilai, kepuasan pelanggan, loyalitas pelanggan, kecenderungan mencari variasi
\end{abstract}

\section{PENDAHULUAN}

Saat ini tingkat persaingan organisasi bisnis sangat tinggi. Untuk bisa bertahan organisasi harus bisa menghasilkan produk bernilai superior dan pelayanan yang berkualitas sehingga pelanggan akan merasa puas dan menjadi loyal. Loyalitas merupakan aset bernilai yang dapat memberikan profit besar bagi perusahaan karena dapat membantu perusahaan dalam memperoleh keuntungan kompetitifnya

Loyalitas muncul karena adanya suatu rasa kepercayaan dari pelanggan setelah menggunakan suatu produk. Kepuasan pelanggan terjadi apabila harapan pelanggan sesuai dengan apa yang dialami dan dirasakannya, bahkan melebihi harapannya (Westbrook, 1980). Pada saat perusahaan tidak mampu untuk memenuhi keinginan dan harapan tersebut maka kemungkinan besar konsumen akan mengalami ketidakpuasan sehingga mereka akan mencari 
alternatif lain (variety seeking) pada konsumsi berikutnya yang dirasa dapat memenuhi keinginan dan harapannya.

Penelitian ini merupakan replikasi dari penelitian yang dilakukan oleh Yang dan Peterson (2004) dengan judul "Customer Perceived Value, Satisfaction, and Loyalty: The Role of Switching Costs." Perbedaannya adalah pada penelitian ini menggunakan obyek produk kartu seluler atau produk dengan keterlibatan rendah dan peneliti menambahkan variety seeking sebagai variabel moderasi

Peneliti tertarik melakukan penelitian ini karena untuk menciptakan loyalitas pelanggan diperlukan pemahaman yang jelas mengenai perceived value dengan melihat peran variety seeking dalam mempengaruhi hubungan kepuasan pada loyalitas, sehingga perusahaan dapat menambah keuntungannya yaitu dengan cara meningkatkan dan menjaga konsumen mereka untuk tetap loyal.

Penelitian ini menggunakan produk kartu seluler dengan pertimbangan karena saat ini semakin banyak produk kartu seluler yang muncul di pasaran dengan menawarkan berbagai macam merek dan variasi yang berbeda. Di samping itu, konsumen cenderung akan melakukan variety seeking dalam membelinya karena keterlibatan konsumen dalam membeli produk tersebut rendah dan produk tidak terlalu beresiko.

Dari berbagai hal di atas dan mengingat pentingnya perceived value dan kepuasan yang tinggi bagi perusahaan dalam menciptakan loyalitas untuk mencapai tujuannya dan untuk membuktikan pengujian secara empirik maka peneliti merumuskan permasalahan dalam penelitian ini sebagai berikut:

1. Apakah perceived value berpengaruh pada loyalitas pelanggan?

2. Apakah kepuasan berpengaruh pada loyalitas pelanggan?

3. Apakah variety seeking memoderasi pengaruh kepuasan pada loyalitas pelanggan?

\section{TINJAUAN PUSTAKA}

\section{Perceived Value}

Perceived value merupakan dasar fundamental bagi seluruh aktivitas pemasaran, dan nilai yang tinggi adalah salah satu motivasi utama pembelian oleh konsumen. Menurut Lai (2004) perceived value adalah penilaian konsumen secara keseluruhan terhadap manfaat produk dengan didasarkan pada apa yang mereka terima dan apa yang mereka berikan. Persepsi konsumen terhadap value dapat didefinisikan dalam beberapa pengertian yaitu value adalah harga rendah, value adalah apapun yang diinginkan oleh konsumen dari produk, value adalah kualitas yang diperoleh untuk harga dan value adalah apa yang didapat untuk apa yang telah diberikan. Perceived value adalah evaluasi calon konsumen terhadap manfaat secara keseluruhan dan seluruh biaya yang ditawarkan dan alternatif yang diterima (Kotler dan Keller, 2006).

\section{Kepuasan Pelanggan}

Kepuasan pelanggan adalah evaluasi secara keseluruhan yang didasarkan pada konsumsi pembelian dan pengalaman (Pappu dan Quester, 2006). Kepuasan pelanggan juga dapat didefinisikan sebagai kepuasan yang didasarkan pada hasil (outcome) atau proses. Outcome merupakan hasil akhir dari pengalaman mengkonsumsi, sedangkan proses menekankan pada perceptual, evaluasi dan proses psikologi yang berkontribusi pada kepuasan pelanggan (Pizam dan Ellis, 1999). Kepuasan pelanggan merupakan outcome dari pembelian dan penggunaan sebagai hasil perbandingan yang dilakukan oleh konsumen terhadap apa yang diterima oleh 
konsumen (rewards) dan biaya pembelian dalam hubungannya untuk mengantisipasi konsekuensi (Pappu dan Quester, 2006).

Secara umum kepuasan dapat dikonsepkan yaitu apakah produk atau pelayanan memenuhi harapan pelanggan yang nantinya akan sangat menentukan tingkat kepuasan atau ketidakpuasan mereka. Pemenuhan kepuasan dibawah harapan mereka atau adanya ketidaksesuaian yang negatif akan mengakibatkan ketidakpuasan yaitu pernyataan dari ketidaksesuaian kognitif/ afektif disebabkan oleh pengembalian yang tidak sesuai dengan sumber daya yang dibelanjakan oleh konsumen pada tahap pembelian atau proses konsumsi (Keiningham et al., 2006).

\section{Loyalitas Pelanggan}

Loyalitas adalah kesanggupan untuk membeli kembali suatu produk/ jasa yang lebih disukai secara konsisten di masa yang akan datang, dengan demikian menyebabkan merek yang samamembeli sekumpulan merek yang sama, disamping pengaruh situasi dan usaha pemasaran yang potensial menyebabkan berubahnya perilaku (Taylor et al., 2004). Loyalitas muncul ketika sikap terhadap merek dinyatakan dalam perilaku pembelian yang berulang (Anderson dan Srinivasan, 2003).

\section{Variety Seeking}

Menurut Raju (1980) variety seeking adalah perilaku yang tidak disebabkan oleh ketidakpuasan semata. Individu yang melakukan variety seeking tidak selalu disebabkan oleh ketidakpuasan terhadap merek sebelumnya. Perilaku variety seeking muncul pada saat konsumen merasa terpenuhi atau bosan pada karakteristik produk yang dikonsumsi sebelumnya. Perilaku variety seeking dapat disebabkan oleh kebosanan pada atribut produk (McAlister,1982). Menurut Knox dan Walker (2001) dalam penelitiannya tentang peran loyalitas merek sebagai ukuran utama dari keefektifan pemasaran merek dan ukuran parsial ekuitas merek menemukan bahwa variety seeking merupakan salah satu bentuk dari beberapa tipe pembelian konsumen.

\section{PERUMUSAN HIPOTESIS}

\section{Perceived Value berpengaruh positif terhadap loyalitas pelanggan}

Loyalitas konsumen dapat terwujud dalam beberapa bentuk yaitu attitudinal loyalty, behavioral loyalty dan composite loyalty yang merupakan kombinasi dari behavioral dan attitudinal loyalty. Berdasarkan pada penelitian yang dilakukan oleh Pura (2005) yang menguji pengaruh dimensi perceived value yaitu monetary, convinience, social, emotional, conditional dan epistemic value pada komponen attitudinal dan behavioral loyalty yaitu komitmen dan niat berperilaku ditemukan bahwa niat berperilaku lebih banyak dipengaruhi oleh conditional value. Disamping itu juga ditemukan bahwa komitmen dapat ditingkatkan melalui emotional value dan conditional value dengan fokus pada pengalaman pelayanan yang menyenangkan bagi konsumen. Perceived value dapat meningkatkan keinginan untuk membeli dan mengurangi keinginan konsumen untuk mencari alternatif lain (Pura, 2005).

Studi yang dilakukan oleh Johnson et al., (2006) menemukan bahwa perceived value memiliki pengaruh yang positif pada niat konsumen untuk loyal. Perceived value sebagai determinan utama dari loyalitas pelanggan. Persepsi pelanggan terhadap value secara langsung berpengaruh pada niat untuk melakukan pembelian kembali (Bolton dan Drew, 1991) atau keinginan untuk membeli kembali (Doods et al., 1991). Berdasarkan uraian tersebut maka hipotesis yang diajukan adalah: 
$\mathrm{H}_{1}$ : Perceived value berpengaruh secara positif pada loyalitas pelanggan

\section{Kepuasan pelanggan berpengaruh positif terhadap loyalitas pelanggan}

Kepuasan pelanggan dan loyalitas memiliki korelasi yang tinggi namun merupakan dua konstruk yang terpisah (Leverin dan Liljander, 2006). Menurut Yu dan Dean (2001) pada saat terdapat hubungan secara langsung antara kepuasan pelanggan dan loyalitas akan ditunjukkan menjadi komplek dan asymmetric. Beberapa teori dan bukti empirik menunjukkan adanya hubungan antara kepuasan dengan ingatan pelanggan dan loyalitas pelanggan. Kepuasan merupakan variabel penting dalam menjelaskan loyalitas (Aaker dan Heskett dalam Rauyruen dan Miller, 2007).

Kepuasan pelanggan adalah syarat yang dibutuhkan untuk loyalitas pelanggan yang nantinya akan mengarahkan pada pertumbuhan laba dan kinerja (Pappu dan Quester, 2006). Pelanggan akan loyal karena mereka terpuaskan dan ingin menjalin hubungan secara terus menerus dengan perusahaan (Andreassen dan Lindestad, 1998). Konsumen yang terpuaskan akan lebih menyukai untuk membeli produk atau jasa yang sama secara berulang, melindungi penawaran kompetitif dari pesaing dan menggenerasikan informasi positif word of mouth (Chiou dan Chi Sen, 2006). Berdasarkan uraian diatas maka hipotesis ke tiga yang diajukan adalah:

$\mathrm{H}_{2}$ : Kepuasan pelanggan berpengaruh secara positif pada loyalitas pelanggan

\section{Variety Seeking Memoderasi Pengaruh Kepuasan Pada Loyalitas}

Di dalam konteks konsumen, pilihan terhadap produk yang berulang akan mengurangi stimulus potensial konsumen dalam melakukan pembelian karena pilihan tidak lagi baru atau komplek bagi konsumen. Hal ini mengarah pada persepsi kebosanan dan konsumen akan berusaha untuk meningkatkan stimulus dengan beralih pada beberapa pilihan produk yang berbeda (Menon dan Kahn, 1995). Menurut Jensen dan Hansen (2006) beralihnya pada merek lain merupakan hasil dari kebutuhan konsumen untuk mengurangi kebosanan atau kebutuhan untuk stimulus sensorik dengan mencari variasi. Berdasarkan uraian tersebut maka hipotesis ke lima yang diajukan adalah :

$\mathrm{H}_{3}$ : Variety seeking memoderasi pengaruh kepuasan pelanggan terhadap loyalitas pelanggan

\section{KERANGKA PENELITIAN}

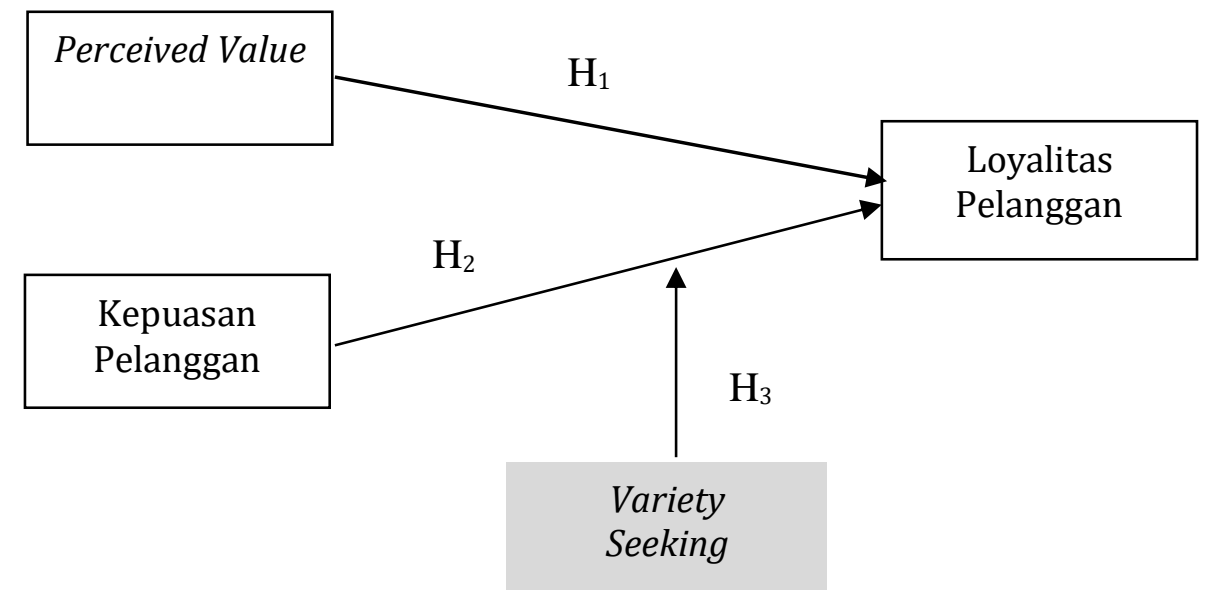

Gambar 1. Kerangka Penelitian 


\section{METODE PENELITIAN}

\section{Tekhnik dan Prosedur Pengumpulan Data}

Penelitian ini adalah penelitian kuantitatif yang dilakukan dengan menggunakan metode survey dalam pengumpulan data. Peneliti mengumpulkan data secara langsung dengan membagikan kuesioner untuk diisi kepada responden yang memiliki kriteria sebagaimana yang ditentukan

\section{Metode Pengambilan Sampel}

Metode pemilihan sampel dalam penelitian ini dilakukan secara non probability dengan teknik purposive sampling. Alasan pengambilan sampel dilakukan secara non probability karena peneliti tidak memiliki sampling frame dalam penelitian ini. Teknik purposive sampling atau sampel bersyarat digunakan berdasarkan pada kriteria yaitu pengguna kartu seluler 18-24 tahun.

\section{Metode Analisis Data}

Metode analisis data yang digunakan adalah multiple regression analysis dan moderated regression analysis. Analisis data dilakukan dengan regresi menggunakan bantuan software SPSS for windows. Moderated regression analysis merupakan bentuk regresi secara hierarkis untuk menentukan hubungan antara dua variabel yang dipengaruhi oleh variabel ketiga atau moderasi (Hair et al., 2006).

\section{HASIL PENELITIAN DAN ANALISIS PEMBAHASAN}

\section{Hasil Pengujian Hipotesis}

Hasil pengujian hipotesis 1 dan 2 dengan menggunakan multiple regression analysis menunjukkan hasil sebagai berikut :

Tabel 1. Hasil Analisis Regresi Berganda

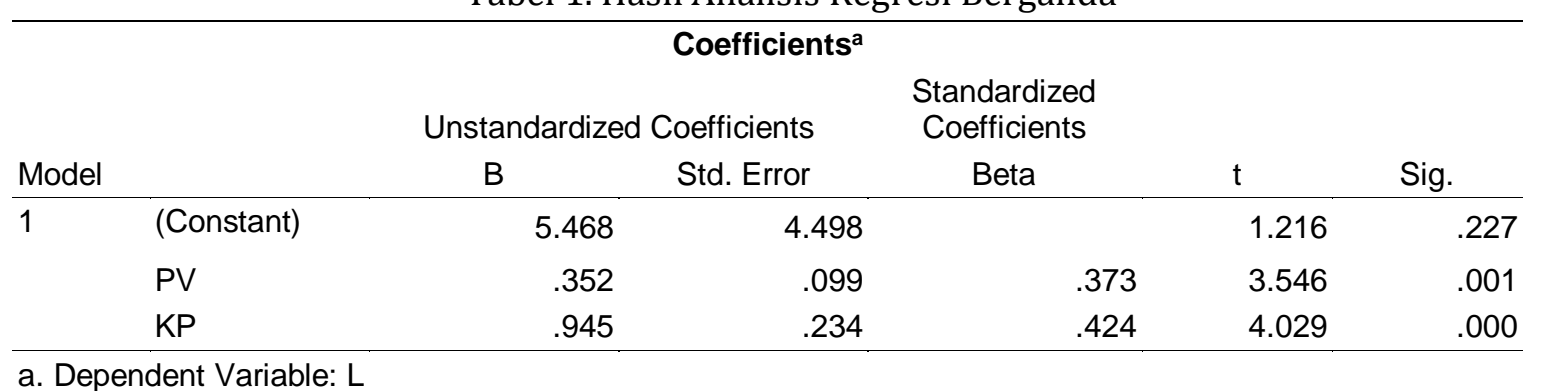

Berdasarkan hasil analisis regresi untuk menguji hipotesis 1 dan 2 di atas, diperoleh hasil nilai $t$ hitung $>\mathrm{t}$ tabel dan nilai sig $<0,05$, sehingga hipotesis 1 dan 2 dalam penelitian ini dapat dinyatakan diterima.

Hasil pengujian hipotesis 3 dengan menggunakan moderated regression analysis menunjukkan hasil sebagai berikut : 
Pengaruh Perceived Value Dan Kepuasan Pada Loyalitas Pengguna Kartu Seluler di Kota Purwokerto Dengan Variabel Variety Seeking Sebagai Variabel Moderasi

Tabel2. Hasil Analisis Regresi dengan Variabel Moderasi

\begin{tabular}{|c|c|c|c|c|c|c|}
\hline \multicolumn{7}{|c|}{ Coefficients $^{a}$} \\
\hline & & \multicolumn{2}{|c|}{ Unstandardized Coefficients } & $\begin{array}{l}\text { Standardized } \\
\text { Coefficients }\end{array}$ & \multirow[b]{2}{*}{$\mathrm{t}$} & \multirow[b]{2}{*}{ Sig. } \\
\hline \multicolumn{2}{|c|}{ Model } & B & Std. Error & Beta & & \\
\hline \multirow[t]{4}{*}{1} & (Constant) & -41.689 & 21.500 & & -1.939 & .055 \\
\hline & $\mathrm{KP}$ & 3.167 & .889 & 1.422 & 3.561 & .001 \\
\hline & VS & 3.041 & 1.037 & 1.017 & 2.932 & .004 \\
\hline & KP.VS & -.089 & .042 & -1.331 & -2.132 & .036 \\
\hline
\end{tabular}

a. Dependent Variable: L

Berdasarkan hasil analisis moderasi diatas, dapat dilihat interaksi dari kepuasan pelanggan dan variety seeking (KP*VS) memiliki nilai $\mathrm{t}=-2,132$ dengan tingkat signifikansi 0,032 $<0,05$. Hal ini berarti bahwa interaksi KP*VS berpengaruh signifikan terhadap loyalitas. Dengan kata lain Variety seeking dapat memoderasi pengaruh kepuasan pelanggan terhadap loyalitas pelanggan. Hal ini berarti Hipotesis 3 diterima.

\section{PEMBAHASAN HASIL PENELITIAN}

\section{Perceived value berpengaruh secara positif pada loyalitas pelanggan}

Hasil penelitian menunjukan bahwa perceived value berpengaruh positif terhadap loyalitas pelanggan. Dengan menggunakan kartu seluler merek tertentu, pelanggan dapat merasakan berbagai nilai yang didapatkan antara lain nilai fungsional yang berasal dari manfaat produk dan kemampuan produk tersebut untuk memenuhi kebutuhan pelanggan, nilai sosial yang menunjukkan tingkat penerimaan sosial yang diperoleh seseorang karena menggunakan kartu seluler tertentu serta nilai emosional yang menunjukkan perasaan seseorang saat menggunakan merek kartu seluler tertentu. Hasil penelitian ini konsisten dengan penelitian sebelumnya yang dilakukan oleh Yang dan Peterson (2004) yaitu perceived value berpengaruh pada loyalitas, dalam hal ini perceived value akan mengarahkan konsumen menjadi loyal. Hasil penelitian ini juga mendukung penelitian yang dilakukan oleh Luarn dan Lin (2003) yang menunjukkan bahwa perceived value berpengaruh secara positif dan signifikan pada attitudinal loyalty dan behavioral loyalty. Perceived value merupakan determinan yang penting bagi loyalitas pembelian. Loyalitas yang tinggi dapat dicapai ketika perceived value diperbaiki. Temuan ini juga konsisten dengan temuan Lewis dan Soureli (2006), namun sedikit berbeda karena dalam penelitiannya menggunakan setting jasa. Hasil temuan tersebut menunjukkan bahwa perceived value merupakan anteseden dari loyalitas dan jika pelanggan merasa menerima value yang besar maka mereka akan merekomendasikannya pada orang lain dan menjaga dirinya untuk tetap loyal.

Hasil temuan dalam penelitian ini juga memperkuat temuan Durvasula (2004) yang menemukan bahwa value secara positif dan signifikan berpengaruh pada kepuasan dan loyalitas yang terwujud dalam pembelian ulang dan merekomendasikan pada orang lain. Pelanggan yang menghargai value akan menjadi loyal. Pelanggan akan merekomendasikan pada orang lain jika mereka menerima perceived value yang tinggi atau hal tersebut ditunjukkan sebagai value for money.

Kepuasan pelanggan berpengaruh secara positif pada loyalitas pelanggan. 
Penelitian ini menemukan bahwa kepuasan mempengaruhi attitudinal loyalty, behavioral loyalty dan composite loyalty. Pelanggan yang merasa puas akan menunjukkan loyalitasnya dalam bentuk sikap yaitu mereka akan memiliki preferensi merek yang kuat, komitmen, dan niat beli. Disamping itu mereka yang terpuaskan cenderung memiliki perilaku untuk membeli merek yang sama. Temuan berikutnya dalam penelitian ini menunjukkan bahwa pelanggan yang puas memiliki sikap dan perilaku (composite) yang kuat terhadap merek tertentu. Hasil tersebut mendukung penelitian yang dilakukan oleh Yang dan Peterson (2004) yaitu kepuasan berpengaruh pada loyalitas.

Temuan dalam penelitian ini juga mendukung penelitian yang dilakukan oleh Donio' et al., (2006) yang menunjukkan bahwa kepuasan merupakan anteseden dari loyalitas pelanggan yang terwujud dalam attitudinal loyalty dan behavioral loyalty. Attitudinal loyalty dihubungkan dengan kepercayaan pelanggan yang ditujukan pada aktivitas perusahaan dan produk, sementara komitmen ditunjukkan oleh keinginan konsumen untuk terus menjalin hubungan, niat pembelian yang eksklusif, sikap word of mouth, harapan untuk selalu menggunakan merek produk yang sama dalam jangka waktu yang lama, sensitifitas harga dan persepsi loyalitas. Sedangkan behavioral loyalty dihubungkan dengan jumlah yang dibeli, jumlah pesanan, frekuensi pembelian, return debt, interaksi, way of payment, way of order dan program loyalitas.

Hasil penelitian ini juga mendukung temuan Terbelanche dan Boshoff (2006), namun sedikit berbeda dalam setting produk yang digunakan. Penelitian tersebut mengenai pengaruh kepuasan pembelanja dengan pengalamannya berbelanja di toko pada loyalitas. Kepuasan konsumen dengan pengalamannya berbelanja di toko digunakan untuk memprediksi dua ukuran loyalitas yaitu attitudinal dan behavioral loyalty. Hasil penelitiannya menunjukkan bahwa kepuasan dengan pengalaman berbelanja berpengaruh pada loyalitas. Kepuasan akan menentukan sikap konsumen terhadap retailer yang pada akhirnya akan berpengaruh pada jumlah uang yang dibelanjakan dari waktu ke waktu.

\section{Variety Seeking Memoderasi Pengaruh Kepuasan Pada Loyalitas Pelanggan.}

Koefisien regresi $\mathrm{KV}^{*} \mathrm{VS}$ pada persamaan kedua bertanda negatif. Hal ini menunjukkan bahwa interaksi dari kepuasan pelanggan dan variety seeking akan menghasilkan loyalitas pelanggan yang lebih rendah. Hal ini berarti pula bahwa pada saat kepuasan tinggi namun dengan ditunjang dengan keinginan mencari variasi yang tinggi (variety seeking yang tinggi) maka loyalitas pelanggan dapat menjadi rendah.

Hasil temuan ini konsisten dengan temuan Raju (1980) yang menemukan bahwa individu yang melakukan variety seeking tidak selalu disebabkan oleh ketidakpuasan mereka. Individu akan mencari variasi ketika merasa bosan pada pilihan sebelumnya. Hal ini diperkuat oleh temuan Van Trijp et al., (1996) yaitu individu akan mencari variasi karena adanya perasaan jenuh atau bosan.

Hasil penelitian ini juga mendukung Mc Alister (1982) yang menunjukkan bahwa perilaku variety seeking yang terjadi pada individu disebabkan karena kejenuhan mereka pada atribut produk. Individu yang secara berulang-ulang mengkonsumsi suatu atribut produk pada awalnya akan memberikan evaluasi yang positif, namun preferensi pada atribut produk tersebut akan menurun dari waktu ke waktu. 


\section{KESIMPULAN DAN IMPLIKASI}

\section{Kesimpulan}

Dari hasil analisis data yang telah diuraikan dari penelitian ini, maka dapat ditarik kesimpulan sebagai berikut bahwa perceived value berpengaruh positif dan signifikan terhadap loyalitas pelanggan. Hal ini berarti bahwa perasaan mendapatklan nilai atas produk kartu telepon yang digunakan akan meningkatkan loyalitas pelanggan. Pengujian hipotesis yang kedua menunjukkan hasil variabel kepuasan pelanggan berpengaruh positif dan signifikan terhadap loyalitas pelanggan yang menunjukkan bahwa perasaan puas terhadap produk kartu telepon seluler yang digunakan akan meningkatkan loyalitas pelanggan. Pengujian hipotesis yang ketiga menunjukkan bahwa variety seeking merupakan variabel yang dapat secara memoderasi pengaruh variabel kepuasan pelanggan terhadap loyalitas pelanggan.

\section{Implikasi Hasil Penelitian}

\section{Implikasi Teoritikal}

Penelitian ini telah berhasil membuktikan beberapa teori atau literatur pemasaran yang menyatakan bahwa perceived value berpengaruh secara positif dan signifikan pada loyalitas (Bolton dan Drew, 1991., Doods et al., 1991., Yang dan Peterson, 2004., Luarn dan Lin, 2003 dan Durvasula, 2004). Hasil penelitian ini menunjukkan bahwa perceived value dan kepuasan mempengaruhi loyalitas pelanggan yang diidentifikasi dengan menggunakan tiga pendekatan yaitu attitudinal loyalty, behavioral loyalty dan composite loyalty. Penelitian ini juga menemukan bahwa pengaruh kepuasan pada loyalitas secara signifikan dimoderasi oleh variety seeking. Perceived value memberikan kontribusi positif pada kepuasan dan loyalitas. Meskipun penelitian ini berhasil menunjukkan pengaruh perceived value pada loyalitas, namun tidak menguji bagaimana tingkat kepuasan pelanggan akan berubah sesuai dengan variasi perceived value. Oleh karena itu perlu penelitian lebih lanjut yang menguji hubungan perceived value dan kepuasan dalam membentuk loyalitas yaitu bagaimana perceived value secara positif dan signifikan dihubungkan dengan tingkatan kepuasan pelanggan.

\section{Implikasi Praktik}

Saat ini perusahaan akan menghadapi tantangan yang berat karena situasi persaingan yang semakin tajam dan pelanggan yang semakin pintar dalam memilih suatu merek produk. Hal ini memaksa bagi setiap pemasar untuk selalu fokus pada kepuasan pelanggan dengan cara meningkatkan value yang ditawarkan untuk mendukung terciptanya loyalitas pelanggan. Sementara itu, pemasar juga harus bisa mempelajari bagaimana sikap dan perilaku konsumennya dengan senantiasa mengetahui kebutuhan dan keinginan mereka terhadap produk yang ditawarkan. Hal ini penting dilakukan karena untuk menghindari perilaku variety seeking yang dilakukan oleh pelangan.

Program-program pemasaran perlu didesain sebaik mungkin untuk mempertahankan pelanggan yang sudah ada dan menarik pelanggan dari pesaing. Program-program pemasaran tersebut diantaranya adalah dengan melakukan promosi dan iklan yang menawarkan value tinggi menggunakan orang yang terkenal, meningkatkan perceived value seperti menawarkan sample produk dengan pertimbangan bahwa konsumen akan merasa yakin terhadap produk, memperbaiki kemasan dengan memberikan bonus karena konsumen akan merasa telah memperoleh sesuatu yang lebih dari jumlah uang yang dikeluarkan, atau bahkan menjual produk 
dengan harga yang tinggi karena konsumen biasanya akan menghubungkan bahwa semakin tinggi harga maka kualitas produk akan semakin baik.

\section{DAFTAR PUSTAKA}

Anderson, R.E. and Srinivasan, S.S. 2003. "E-Satisfaction and E-Loyalty: A Contingency Framework," Psychology \& Marketing, Vol. 20, No. 2, pp. 123-138.

Assael, H. 2001. "Consumer Behaviour \& Marketing Action," $6^{\text {th }}$ ed. Singapore: Thompson Learning.

Caruana, A. and Fenech, N. 2005. "The Effect of Perceived Value and Overall Satisfaction on Loyalty: A Study Among Dental Patiens," Journal of Medical Marketing, Vol. 5, No. 3, pp. 245-255.

Darsono, L.I. and Junaedi, C.M., 2006. "An Examination of Perceived Quality, Satisfaction, and Loyalty Relationship-Applicability of Comparative and Noncomparative Evaluation," Gadjah Mada International Journal of Business, Vol. 8, No. 3, pp. 323-342.

Donio', J., Massari, P. and Passiante, G.2006. "Customer Satisfaction and Loyalty in A Digital Environment: An Empirical Test," Journal of Consumer Marketing, Vol. 23, No. 7, pp. 445-457.

Durvasula, S., Lysonski, S., Mehta, S.C. and Tang, B.P.2004."Forging Relationships With Services: The Antecedents That Have an Impact on Behavioural Outcomes in The Life Insurance Industry," Journal of Financial Services Marketing, Vol. 8, No. 4, pp. 314-326.

Kotler, P. and K. Keller.2006. Marketing Management, $12^{\text {th }}$ ed. Upper Saddle River, NJ: Pearson Education, Inc.

Lai, T.L. 2004. "Service Quality and Perceived Value's Impact on Satisfaction, Intention and Usage of Short Message Service (SMS)," Information System Frontiers, Vol. 6, No. 4, pp. 353-368.

Lewis, B.R. and Soureli, M. 2006. "The Antecedents of Consumer Loyalty in Retail Banking," Journal of Consumer Behavior, Vol. 5, pp. 15-31.

Lin, Chia C. 2003. "The Role of Customer Perceived Value in Generating Customer Satisfaction: An EBussiness Perspective," Journal of Research in Marketing \& Entrepreneurship, Vol. 5, No. 1, pp. 2539.

McAlister, L. 1982. "A Dynamic Attribute Satiation Model of Variety Seeking Behavior," Journal of Consumer Reearch, Vol. 9, pp. 141-150.

Menon, S. and Kahn, B.E. (1995), "The Impact of Context on Variety Seeking in Product Choices," Journal of Consumer Research, Vol. 22, pp. 285-295.

Pappu, R. and Quester, P. (2006), "Does Customer Satisfaction Lead to Improved Brand Equity? An Empirical Examination of Two Categories of Retail Brands," Journal of Product and Brand Management, Vol. 15, pp. 4-14.

Patterson, P.G. and Spreng, R.A. (1997), “Modelling The Relationship Between Perceived Value, Satisfaction and Repurchase Intentions in a Business To Business, Services Context: An Empirical Examination," International Journal of Service Industry Management, Vol. 8, No. 5, pp. 414-434. 
Pengaruh Perceived Value Dan Kepuasan Pada Loyalitas Pengguna Kartu Seluler di Kota Purwokerto Dengan Variabel Variety Seeking Sebagai Variabel Moderasi

Payne, A. and Holt, S. (2001), "Diagnosing Customer Value: Integrating the Value Process and Relationship Marketing," British Journal of Management, Vol. 12, pp. 159-182.

Pura, Minna (2005), "Linking Perceived Value and Loyalty in Location-Based Mobile Services," Managing Service Quality, Vol. 15, No. 6, pp. 509-538.

Raju, P.S. (1980), “Optimum Stimulation Level: Its Relationship to Personality, Demographic, and Exploratory Behavior," Journal of Consumer Research, Vol. 12, No. 7, pp. 272-281.

Spais, G.S. and Vasileiou, K.Z. (2006), "An Ordinal Regression Analysis For The Explanation of Consumer Overall Satisfaction in The Food Marketing Context: The Managerial Implications to Consumer Strategy Management at A Store Level," Database Marketing \& Customer Strategy Management, Vol. 14, No. 1, pp. 51-73.

Terblanche, N.S. and Boshoff, C. (2006), "The Relationship Between A Satisfactory in Store Shopping Experience and Retailer Loyalty," Vol. 37, No. 2, pp. 33-43.

Van Trijp, H.C.M., W.D. Hoyer and J.J. Inman (1996), "Why Switch? Product Category-Level Explanations For True Variety Seeking Behavior," Journal of Marketing Research, Vol.XXXIII, August, pp.281-292.

Wang, Y., Lo, H.P., Chi, R. and Yang, Y. (2004), "An Integrated Framework for Customer Value and Customer Relationship Management Performance: A Customer Based Perspective From China," Managing Service Quality, Vol. 14, No. 2/3, pp. 169-182.

Westbrook, R.A. (1980), "Intrapersonal Affective Influences on Consumer Satisfaction with Products," Journal of Consumer Research, Vol. 7, pp. 49-54. 